\title{
Nasopharyngeal colonisation with Streptococcus pneumoniae in malnourished children: a systematic review and meta-analysis of prevalence.
}

Holly C Smith ${ }^{1}$, Esther German ${ }^{2}$, Daniela M Ferreira ${ }^{2}$ and Jamie Rylance ${ }^{2,3}{ }^{*}$

${ }^{1}$ University of Liverpool, Liverpool, UK

${ }^{2}$ Liverpool School of Tropical Medicine, Liverpool, UK

${ }^{3}$ Malawi-Liverpool-Wellcome Programme, Malawi

*Corresponding author: Liverpool School of Tropical Medicine, Pembroke Place, Liverpool, L35QA; 0151705 3775; jamie.rylance@Istmed.ac.uk

Abstract word count: 216

Paper word count (excluding abstract and references): 2005 


\section{Abstract}

Background: Streptococcus pneumoniae is an intermittent commensal organism in the nasopharynx. Colonisation is a prerequisite for disease and malnourished children are especially susceptible to severe infection. This systematic review examines published prevalence rates of pneumococcal colonisation in the upper respiratory tract of chronically malnourished children under the age of five years.

Methods: A systematic literature search was performed using Medline, PubMed, Web of Science and Scopus. After screening, relevant studies were assessed for quality using STROBE criteria. Colonisation data were extracted and a randomeffects model used to pool prevalence estimates.

Findings: Nine studies were included. The prevalence rate of $S$. pneumoniae colonisation in malnourished children during the first month of life ranged from 1.0$2.0 \%$ increasing at 2 months to $53.9-80.0 \%$. Carriage remained similar from 3 months to 60 months at $64.1-88.0 \%$. Meta-analysis showed a pooled prevalence of $67.2 \%$ in $0-3$ months infants $(95 \% \mathrm{Cl}, 55.6-78.7 \%), 77.9 \%$ in 3-6 months infants $(95 \% \mathrm{Cl}, 68.1-87.7 \%)$ and $77.8 \%$ in $6-60$ months infants $(95 \% \mathrm{Cl}, 73.9-81.6 \%)$.

Conclusion: In malnourished children, it is plausible that rates of pneumococcal colonisation are higher than in healthy, well-nourished children. Knowledge of colonisation rates can inform policies on vaccination and ancillary interventions during treatment of malnutrition. Future studies should assess the impact of reducing colonisation on disease rates or transmission in these "at risk" individuals.

Keywords: CARRIER STATE, COLONISATION, MALNUTRITION, STREPTOCOCCUS PNEUMONIAE, UPPER RESPIRATORY TRACT 


\section{Introduction}

Streptococcus pneumoniae (S. pneumoniae) is a leading global cause of respiratorytract infections and invasive disease in young children, the elderly and immunocompromised patients. In 2015 , pneumonia accounted for $16 \%$ of all deaths of children less than five years of age. ${ }^{1}$ Immunisation programmes using pneumococcal conjugate vaccines (PCV) and polysaccharide vaccines (PPV) reduce colonisation rates and mortality from invasive disease in a serotype-specific manner. ${ }^{2}$ Their utility in Low and Middle Income Countries (LMIC) can be limited by cost, variable coverage of locally circulating serotypes, ${ }^{3}$ and the high frequency of individuals with medical conditions that alter their immune responses (such as malnutrition or $\mathrm{HIV}^{4}$ ).

The upper respiratory tract (URT) provides an ecological niche for diverse bacterial populations and S. pneumoniae frequently but asymptomatically colonises the URT, especially in young children. ${ }^{5}$ Progression to mucosal disease (such as sinusitis, otitis media and pneumonia) and invasive pneumococcal disease (IPD) can occur if immunological and mechanical defences are breached and such events are more likely amongst individuals with higher colonisation rates. ${ }^{6}$ Nasopharyngeal aerosolization of $S$. pneumoniae is considered the primary mode of population transmission. ${ }^{7}$ The high rates of $S$. pneumoniae colonisation seen in the under $5 \mathrm{~s}$ partly explain the more frequent disease in this age group and why children are thought to be the main reservoir and vector of spread. ${ }^{8}$

Young children also have incomplete protection against disease due to immature adaptive and innate immunity. ${ }^{9}$ These systems actively sense colonising mucosal bacteria and maintain a balanced regulatory environment. ${ }^{10}$ Higher disease prevalence in LMICs reflects a variety of environmental challenges such as overcrowding, particulate exposure and undernutrition, which can adversely affect mucosal immunity. ${ }^{11}$ Pneumonia, for example, is more frequent and more severe in malnourished children in whom immunological studies have shown reduced cellular immunity, phagocyte function, complement and immunoglobulin and cytokine production. ${ }^{12,13}$

Malnutrition, defined as the insufficient, excessive or imbalanced consumption of nutrients, is attributable to $53 \%$ of deaths associated with infectious diseases among children less than five years of age in impoverished countries. ${ }^{6}$ Malnutrition is 
multifactorial, frequently resulting from inadequate breastfeeding, insufficient food availability and recurrent enteric infections. ${ }^{6,14}$ Protein-energy malnutrition manifests as kwashiorkor (predominantly protein deficiency) and marasmus (protein and energy deficiency). Micronutrient deficiency due to lack of a specific vitamin or mineral may coexist with these or occur in isolation. ${ }^{15}$ Acute malnutrition usually presents as "wasting" (a weight-to-height $Z$ score <-2), compared with "stunting" (a height-to-age $Z$ score $<-2$ ), which suggests chronic malnutrition. ${ }^{16}$

Pneumococcal prevalence data could predict the potential of public health interventions targeting nutrition to prevent $S$. pneumoniae disease and/or transmission. The rates of colonisation in malnourished children is therefore relevant to interventions at the individual and population level. This systematic review and meta-analysis describes these rates in malnourished children under the age of 5 years. 


\section{Methods}

A search of the existing literature was conducted in November 2016 to identify reports of URT pneumococcal colonisation rates in chronically malnourished children aged from 0 to 5 years. We searched PubMed (1955-2016), Medline (1950-2016), Scopus (1960-2016) and Web of Science (1900-2016) using combinations encompassing broad search strings for Streptococcus pneumoniae, nasopharyngeal colonisation (including carriage and carrier states) and chronic malnutrition (including kwashiorkor, marasmus and micronutrient deficiencies determined as per the WHO guidelines for the treatment of severely malnourished children). ${ }^{17}$ Specific search terms and their combinations are shown in Supplementary materials.

Inclusion criteria were: (i) experimental or observational studies; (ii) English language; (iii) reporting data on URT colonisation of $S$. pneumoniae; (iv) subjects included chronically malnourished children; (v) aged 0-5 years. Studies were excluded which: (i) did not report rates of colonisation; (ii) were case series, case reports, letters or editorials. Retrieved papers were first screened by title and abstract then by full text. Further potential publications were identified from the reference list of included articles.

Data were captured by pre-designed proforma. Quality and risk of bias were assessed using the STROBE tool. ${ }^{18}$ Prism (version 7.02, GraphPad, California USA) was used for statistical analysis. Studies were included in meta-analysis if they reported data which allowed calculation of $S$. pneumoniae point prevalence rates and if they included at least 100 participants. Pooled prevalence was calculated using a model which incorporated the study as a random effect and was weighted by the number of participants contributing data. ${ }^{19}$ 


\section{Results}

Sixty-eight citations were identified, of which thirty-three were unique. Nine papers met the inclusion criteria (Figure 1). STROBE quality assessment data are given in Appendix 1.

All studies used conventional microbiology to detect colonisation and followed recommendations made by the $\mathrm{WHO}$ for measuring nasopharyngeal colonisation. ${ }^{20}$ Rayon-tipped swabs were the most frequently used swabs (4/9 studies, $44.4 \%$ ). A single study from Venezuela obtained additional oropharyngeal samples. ${ }^{21}$

Five studies derived from vitamin A supplementation random controlled trials (RCTs): two in India, ${ }^{22,23}$ one in Bangladesh, ${ }^{24}$ and two in The Gambia. ${ }^{25,26}$ One study was a zinc supplementation RCT in Nepal. ${ }^{27}$ Two case-control studies - one in Venezuela ${ }^{21}$, one in The Gambia ${ }^{12}$ - compared colonisation in malnourished children with and without S. pneumoniae infection. One paper was a clinical trial investigating a urinary pneumococcal diagnostic tool in Ecuador. ${ }^{28}$

Reported prevalence of $S$. pneumoniae colonisation in malnourished children aged 0 to 5 years ranged from $1.0 \%$ to $88.0 \%$ (Table 1 ). The prevalence rate of colonisation ranged from 1.0 to $2.0 \%$ at birth, increasing within the first two months of life to $53.9 \%$ to $80.0 \%$. Colonisation rates in the period between 3 to 60 months of life ranged from $64.1 \%$ and $88.0 \%$.

The pooled prevalence estimate of $S$. pneumoniae colonisation was $67.2 \%(95 \% \mathrm{Cl}$, $55.6 \%-78.7 \%)$ in children aged from 0 to $\leq 3$ months, $77.9 \%(95 \% \mathrm{Cl}, 68.1 \%-87.7 \%)$ aged greater than 3 months to $\leq 6$ months and $77.8 \%(95 \% \mathrm{Cl}, 73.9 \%-81.6 \%)$ aged greater than 6 months to $\leq 60$ months (Figure 2).

All nine papers were graded as good quality and design (Appendix 1). Control groups were used and appropriate in eight studies. Intervention trials used malnourished controls without pneumococcal infection, supplemented with placebos. The control group in the Gambian RCT study were provided with a lower-dose vitamin A supplement rather than a placebo. ${ }^{26}$ In Venezuela, matched controls of nearest-age siblings or cousins living in the same household were used. ${ }^{21}$ 


\section{Discussion}

We found nasopharyngeal colonisation to be frequent in children with malnutrition under five years in low- and middle-income countries (53.9\% to $88.0 \%$ from 2 months to 5 years). Pooled prevalence rates increased greatly from $1.0-2.0 \%$ at birth to 53.9 $80.0 \%$ at 2 months, reflecting the point of first acquisition of S. pneumoniae. From 3 months up to 5 years of age, colonisation remains high between 64.1 and $88.0 \%$.

Nasopharyngeal colonisation rates amongst healthy, well-nourished children less than 5 years of age before the introduction of PCV have been previously reported as $64.8 \%$ in low-income and $47.8 \%$ in lower-middle income countries. ${ }^{29}$ The prevalence rates found in these healthy children are lower than those found in our review of malnourished children. This difference may reflect clinical and methodological differences but suggests that prevalence rates of $S$. pneumoniae are higher in malnourished states. Our results are supported by a study in Venezuela that reported colonisation rates of $73 \%$ in children under $5 .^{30}$

Immune changes associated with protein-energy malnutrition are many: atrophic changes to the thymus, leading to poorly developed peripheral lymphoid organs and decreased T cell function and number. ${ }^{14}$ Malnutrition also reduces immunoglobulin $A$ secretion, impairs complement activity and immunoglobulin responses to encapsulated bacteria and, indirectly, decreases phagocytic activity..$^{31,32}$ In a persuasive case-control study, children with stunting in Venezuela were more likely to present with pneumococcal colonisation and acute respiratory tract infection compared to age-matched relatives from the same household. ${ }^{21} \mathrm{~A}$ recent study, not included in our review due to search time limits, found a strong association between stunting and S. pneumoniae colonisation. ${ }^{30}$

The role of micronutrient deficiency and supplementation in acute bacterial infections remains controversial but zinc supplementation is effective in preventing pneumonia, and is recommended by the $\mathrm{WHO}^{33}$ Suboptimal zinc status damages epithelial function and impairs antibody-mediated responses. ${ }^{27} \mathrm{~A}$ case-control study included in our systematic review found a strong interaction between zinc status and $S$. pneumoniae colonisation. ${ }^{27}$ In mice, zinc-deficiency has been associated with higher nasopharyngeal colonisation density of $S$. pneumoniae following pneumococcal challenge and reduced responses to PspA immunisation. ${ }^{33}$ 
Vitamin A deficiency promotes rapid bacterial colonisation in infants, ${ }^{34}$ potentially permitting greater bacterial adherence, colonisation, and infection. ${ }^{23}$ It is known to play a role in immune homeostasis as well as B- and T-cell homing to the intestinal mucosa. ${ }^{35}$ It is plausible that it performs a similar function at the nasal mucosa. Supplementation can reduce infant mortality in areas of endemic deficiency, ${ }^{36}$ although studies examining the specific effects on bacterial colonisation are inconsistent. New-borns in south India dosed with vitamin A had a lower rate of pneumococcal colonisation at 3 months compared to those receiving placebo, but this was not apparent in a similar trial in Bangladesh. ${ }^{23,24} \mathrm{~A}$ third trial comparing high and low dose vitamin A supplementation found no difference in colonisation between groups. ${ }^{26}$

Baseline measurements confirming micronutrient malnutrition were not systematically carried out within the supplementation trials ${ }^{22-25,26,27}$ and deficiency within the population is assumed. However, evidence of deficiency in those geographies was good: $17-37 \%$ of young children within the geographic area studied in south India had low serum retinol levels;22,23,37 the Gambian population had significantly lower levels than expected in the UK ${ }^{38}$; the Bangladesh study reported a high prevalence of maternal night blindness, a clinical sign of vitamin A deficiency; ${ }^{24}$ in the Nepal zinc trial $42 \%$ of children within a previous trial in the same area had low serum zinc concentration. ${ }^{27,39}$

Our review encompassed multiple forms of macro and micronutrient malnutrition which, with limited data, might make pooled rates of colonisation difficult to interpret. The studies reported here represent a relatively limited geographic sample which may not represent the worldwide malnourished population. Additionally, inclusion of studies of malnourished children only does not allow for a detailed appraisal of the association between malnutrition and pneumococcal colonisation. Two studies combined anthropometric measurements of wasting and stunting to define their study population. ${ }^{12,21}$ These represent acute and chronic malnutrition respectively, and each may differently impact mucosal immunity and $S$. pneumoniae colonisation rates.

There is not enough uniformity of reporting of vaccination within the included studies to comment on pneumococcal vaccination within study populations. Vaccines can have a profound effect on serotype prevalence, ${ }^{40,41}$ if not always overall prevalence, and vaccination status could be a confounding variable. 
Other limitations of this study include bias arising from selective publication and methodological limitations. For example, two studies compared colonisation in malnourished children with and without pneumococcal infection. As colonisation is a prerequisite to infection, this may artificially inflate colonisation rate estimates. ${ }^{12,21}$ Studies embedded within trials were not originally designed to deliver a crosssectional representation of the wider population and sampling frames may not have fully accounted for seasonal variation. For example, colonisation rates are higher in the Gambia during the dry season, perhaps due to a combination of atmospheric conditions which promote colonisation and increased transmission due to social factors such as higher school attendance (and therefore intermixing) outside of harvesting seasons. ${ }^{12,42}$

Studies designed specifically to investigate pneumococcal colonisation in a malnourished population are essential for the identification of high-risk groups and to understand their responses to pneumococcal vaccines. There is evidence that both protein-energy malnutrition and micronutrient deficiencies can affect responses to vaccination. ${ }^{43,44}$ The drivers of colonisation rates are complex but well-designed studies could be used to detect other risk factors or confounders for increased $S$. pneumoniae prevalence in the nasopharynx, including the effect on somatic growth. ${ }^{21}$ Importantly, we do not know if colonisation produces antibody-mediated protection in this population as it does in healthy children. ${ }^{45}$

The combination of pneumonia and malnutrition has an enormous impact on child mortality in developing countries. This systematic review found high prevalence of $S$. pneumoniae colonisation in malnourished children under five years of age. Although the available data are limited, S. pneumoniae colonisation appears more prevalent in this population compared to healthy children without malnutrition. Current evidence is insufficient to judge if correction of nutritional deficits would lead to lower colonisation rates.

\section{Declarations}

Funding: None

Conflicts of interest: None declared

Ethical approval: Not required as data are anonymised and openly available. 
Author contributions: All authors contributed to the design, analysis, and writing of the manuscript. 


\section{References}

1. World Health Organization. Pneumonia: Fact sheet 2016.

http://www.who.int/mediacentre/factsheets/fs331/en/ (accessed 29/11/2017).

2. Whitney CG, Farley MM, Hadler J et al. Decline in invasive pneumococcal disease after the introduction of protein-polysaccharide conjugate vaccine. $N$ Engl $J$ Med 2003; 348(18): 1737-46.

3. $\quad$ Gordon SB, Kanyanda S, Walsh AL et al. Poor Potential Coverage for 7Valent Pneumococcal Conjugate Vaccine, Malawi. Emerg Inf Dis 2003; 9(6):747-749

4. Jallow S \& Mahdi SA. Pneumococcal conjugate vaccine in HIV-infected and HIV-exposed, uninfected children. Expert Review of Vaccines 2017; 16(5):453-465

5. Mehr S, Wood N. Streptococcus pneumoniae--a review of carriage, infection, serotype replacement and vaccination. Paediatric respiratory reviews 2012; 13(4): 258-64.

6. Glennie SJ, Williams NA, Heyderman RS. Mucosal immunity in resourcelimited setting: is the battle ground different? Trends in microbiology 2010; 18(11): 487-93.

7. Musher DM. How contagious are common respiratory tract infections? The New England journal of medicine 2003;348(13):1256-66. doi:

10.1056/NEJMra021771 [published Online First: 2003/03/28]

8. Althouse BM, Hammitt LL, Grant L et al. Identifying transmission routes of Streptococcus pneumoniae and sources of acquisitions in high transmission communities. Epidemiol Infect 2017; 145:2750-2758.

9. Bogaert D, De Groot R, Hermans PW. Streptococcus pneumoniae colonisation: the key to pneumococcal disease. Lancet Infect Dis 2004; 4(3): 144-54. 10. Paton JC, Andrew PW, Boulnois GJ, Mitchell TJ. Molecular analysis of the pathogenicity of Streptococcus pneumoniae: the role of pneumococcal proteins. Annu Rev Microbiol 1993; 47: 89-115.

11. Mills RO, Twum-Danso K, Owusu-Agyei S, Donkor ES. Epidemiology of pneumococcal carriage in children under five years of age in Accra, Ghana. Infect Dis (Lond) 2015; 47(5): 326-31.

12. Adegbola RA, Falade AG, Sam BE, et al. The etiology of pneumonia in malnourished and well-nourished Gambian children. Pediatr Infect Dis J 1994; 13(11): 975-82.

13. Zelaya H, Laino J, Villena J, Alvarez S, Aguero G. Lactobacillus rhamnosus CRL1505 beneficially modulates the immuno-coagulative response after pneumococcal infection in immunocompromised malnourished mice. Can J Microbiol 2013; 59(10): 684-93.

14. Schaible UE, Kaufmann SH. Malnutrition and infection: complex mechanisms and global impacts. PLoS Med 2007; 4(5): e115.

15. Waterlow JC. Classification and definition of protein-energy malnutrition. Monogr Ser World Health Organ 1976; (62): 530-55.

16. World Health Organization. WHO child growth standards: length/height for age, weight-for-age, weight-for-length, weight-for-height and body mass index-forage, methods and development: World Health Organization; 2006.

17. World Health Organization. Management of severe malnutrition: a manual for physicians and other senior health workers. Geneva; 1999.

18. Vandenbroucke JP, von Elm E, Altman DG, et al. Strengthening the Reporting of Observational Studies in Epidemiology (STROBE): Explanation and Elaboration. PLOS Medicine 2007; 4(10): e297.

19. Borenstein M, Hedges LV, Higgins JP, Rothstein HR. A basic introduction to fixed-effect and random-effects models for meta-analysis. Res Synth Methods 2010; 1(2): 97-111. 
20. Satzke C, Turner P, Virolainen-Julkunen A, et al. Standard method for detecting upper respiratory carriage of Streptococcus pneumoniae: updated recommendations from the World Health Organization Pneumococcal Carriage Working Group. Vaccine 2013; 32(1): 165-79.

21. Verhagen LM, Gomez-Castellano K, Snelders E, et al. Respiratory infections in Enepa Amerindians are related to malnutrition and Streptococcus pneumoniae carriage. The Journal of infection 2013; 67(4): 273-81.

22. Coles CL, Kanungo R, Rahmathullah L, et al. Pneumococcal nasopharyngeal colonization in young South Indian infants. Pediatr Infect Dis J 2001; 20(3): 289-95.

23. Coles CL, Rahmathullah L, Kanungo R, et al. Vitamin A supplementation at birth delays pneumococcal colonization in South Indian infants. J Nutr 2001; 131(2): 255-61.

24. Coles CL, Labrique A, Saha SK, et al. Newborn vitamin A supplementation does not affect nasopharyngeal carriage of Streptococcus pneumoniae in Bangladeshi infants at age 3 months. J Nutr 2011; 141(10): 1907-11.

25. Darboe MK, Fulford AJ, Secka O, Prentice AM. The dynamics of nasopharyngeal streptococcus pneumoniae carriage among rural Gambian motherinfant pairs. BMC Infect Dis 2010; 10: 195.

26. Darboe MK, Thurnham DI, Morgan G, et al. Effectiveness of an early supplementation scheme of high-dose vitamin A versus standard WHO protocol in Gambian mothers and infants: a randomised controlled trial. Lancet 2007; 369(9579): 2088-96.

27. Coles CL, Sherchand JB, Khatry SK, et al. Zinc modifies the association between nasopharyngeal Streptococcus pneumoniae carriage and risk of acute lower respiratory infection among young children in rural Nepal. J Nutr 2008; 138(12): 2462-7.

28. Hamer DH, Egas J, Estrella B, MacLeod WB, Griffiths JK, Sempertegui F. Assessment of the Binax NOW Streptococcus pneumoniae urinary antigen test in children with nasopharyngeal pneumococcal carriage. Clin Infect Dis 2002; 34(7): 1025-8.

29. Adegbola RA, DeAntonio R, Hill PC, et al. Carriage of Streptococcus pneumoniae and other respiratory bacterial pathogens in low and lower-middle income countries: a systematic review and meta-analysis. PLoS One 2014; 9(8): e103293.

30. Verhagen LM,Hermsen M, Rivera-Olivero IA, et al. Nasopharyngeal carriage of repiratory pathogens in Warao Amerindians: significant relationship with stunting. Tropical Medicine and International Health 2017; 22(4): 407-414.

31. Caulfield LE, de Onis M, Blossner M, Black RE. Undernutrition as an underlying cause of child deaths associated with diarrhea, pneumonia, malaria, and measles. Am J Clin Nutr 2004; 80(1): 193-8.

32. Savino W. The thymus gland is a target in malnutrition. Eur J Clin Nutr 2002; 56 Suppl 3: S46-9.

33. Strand TA, Hollingshead SK, Julshamn K, Briles DE, Blomberg B, Sommerfelt $H$. Effects of zinc deficiency and pneumococcal surface protein a immunization on zinc status and the risk of severe infection in mice. Infect Immun 2003; 71(4): 200913.

34. Chandra RK. Increased bacterial binding to respiratory epithelial cells in vitamin A deficiency. BMJ 1988; 297(6652): 834-5.

35. Oliveira LM, Teixeira FME, Sato MN. Impact of Retinoic Acid on Immune Cells and Inflammatory Diseases. Mediators of inflammation 2018; 2018: 3067126.

36. Klemm RD, Labrique AB, Christian $P$, et al. Newborn vitamin A supplementation reduced infant mortality in rural Bangladesh. Pediatrics 2008; 122(1): e242-50.

37. Rahi JS, Sripathi S, Gilbert CE, Foster A. Childhood blindness due to vitamin A deficiency in India: regional variations. Arch Dis Child 1995; 72(4): 330-3. 
38. Bates CJ, Villard L, Prentice AM, Paul AA, Whitehead RG. Seasonal variations in plasma retinol and carotenoid levels in rural Gambian women. Trans $R$ Soc Trop Med Hyg 1984; 78(6): 814-7.

39. Tielsch JM, Khatry SK, Stoltzfus RJ, et al. Effect of daily zinc supplementation on child mortality in southern Nepal: a community-based, cluster randomised, placebo-controlled trial. Lancet 2007; 370(9594): 1230-9.

40. Devine VT, Cleary DW, Jefferies JMC et al. The rise and fall of pneumococcal serotypes carried in the PCV era. Vaccine 2017; 35(9):1293-1298.

41. Usuf E, Bottomley C, Bojang E et al. Persistence of nasopharyngeal pneumococcal vaccine serotypes and increase of non-vaccine serotypes among vaccinated infants and their mothers five years after PCV13 introduction in The Gambia. Clin Infect Dis 2018; ISSN 1058-4838 DOI:https://doi.org/10.1093/cid/ciy726 42. Bojang A, Jafali J, Egere UE, et al. Seasonality of Pneumococcal Nasopharyngeal Carriage in Rural Gambia Determined within the Context of a Cluster Randomized Pneumococcal Vaccine Trial. PLoS One 2015; 10(7): e0129649.

43. Rho S, Kim H, Shim SH et al. Protein energy malnutrition alters mucosal IgA responses and reduces mucosal vaccine efficacy in mice. Immunology letters 2017; 190:247-256.

44. Penkert RR, Iverson A, Rosch JW \& Hurwitz JL. Prevnar-13 vaccine failure in a mouse model for vitamin A deficiency. Vaccine 2017; 35(46):6264-6268.

45. Zhang Q, Bernatoniene J, Bagrade L, et al. Serum and mucosal antibody responses to pneumococcal protein antigens in children: relationships with carriage status. Eur J Immunol 2006; 36:46-57.

46. Riboldi BP, Quevedo A, Fuchs S et al. Respiratory Infections in Enepa Amerindians; interpret with caution. Journal of Infection 2013; 67(4)

47. Verhagen LM, Gomez-Castellano K, Snelders E et al. Post hoc power calculations and statistical analysis of case control studies: reply to Riboldi et al. Journal of Infection 2014; 68(2):194-195. 


\section{Figure 1}

Flow chart showing selection of articles






\section{Figure 2}

Meta-analysis of S. pneumoniae carriage in malnourished children under 5 years of age. Children aged: (A) 0 to $\leq 3$ months, $(B)<3$ to $\leq 6$ months, $(C)<6$ to $\leq 60$ months. The prevalence carriage rate for each study is represented by a square. An unfilled diamond represents the pooled prevalence estimate. The $95 \%$ confidence interval (Cl) for each study is denoted by a horizontal line crossing the symbol. Weight for the random effects analysis for each study is given (\%).

(A)

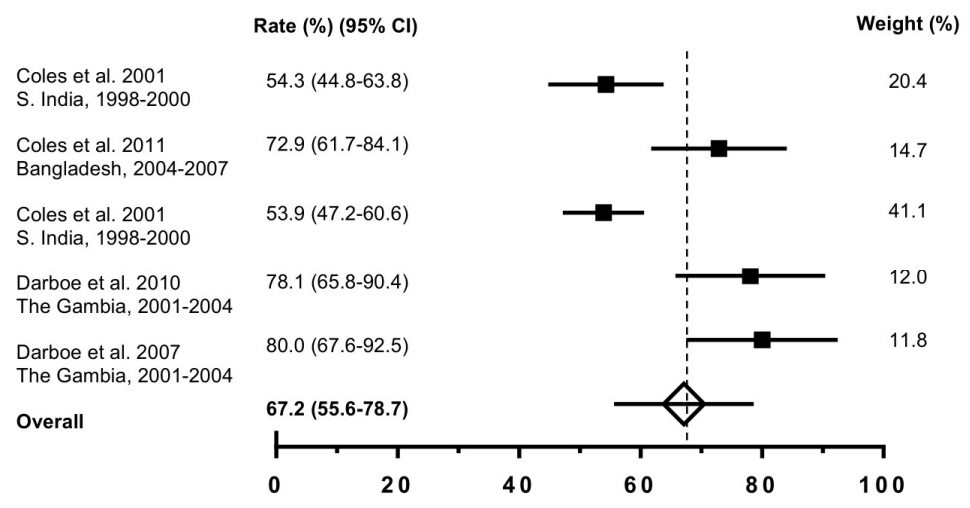

Prevalence of S. pneumoniae carriage in children 0 to $\leq 3$ months (\%)

(B)

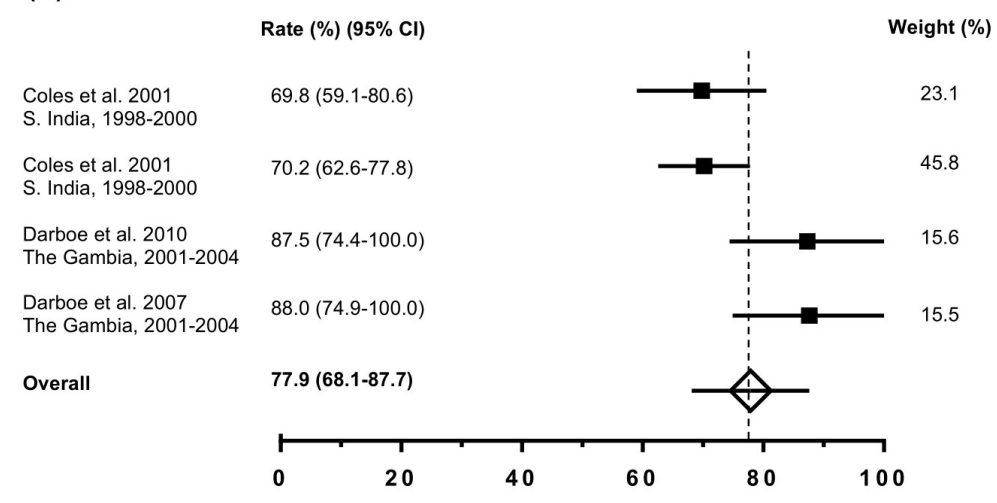

Prevalence of S. pneumoniae carriage in children $<3$ to $\leq 6$ months (\%)

(C)

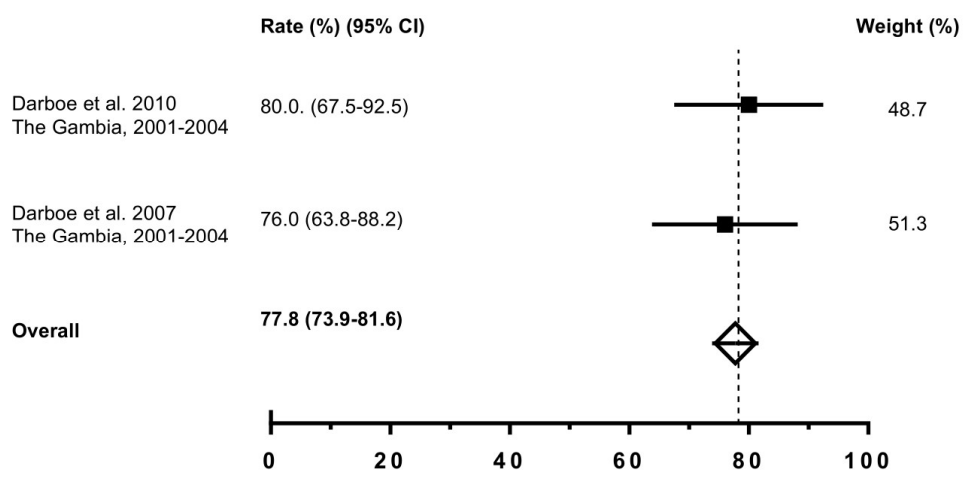

Prevalence of S. pneumoniae carriage in children $<6$ to $\leq 60$ months (\%) 


\section{Table 1}

Summary table of studies reporting colonisation rates of Streptococcus pneumoniae in chronically malnourished children.

\begin{tabular}{|c|c|c|c|c|c|c|c|c|c|c|c|c|c|}
\hline \multirow[t]{2}{*}{ Study } & \multirow[t]{2}{*}{ Study period } & \multirow[t]{2}{*}{ Country } & \multirow[t]{2}{*}{ Condition } & \multirow[t]{2}{*}{ Population } & \multirow[t]{2}{*}{$\mathrm{n}$} & \multicolumn{8}{|c|}{ Streptococcus pneumoniae colonisation rate (\%) } \\
\hline & & & & & & Birth & $2 m$ & $3 m$ & $4 \mathrm{~m}$ & $5 \mathrm{~m}$ & $6 m$ & $12 m$ & Overall \\
\hline $\begin{array}{l}\text { Coles et } \\
\text { al. } 2001^{22}\end{array}$ & $\begin{array}{l}\text { Oct } 1998- \\
\text { Jan } 1999\end{array}$ & South India & Vit A def & New-borns given placebo & 232 & & 54.3 & & 67.9 & & 69.8 & & \\
\hline $\begin{array}{l}\text { Coles et } \\
\text { al. } 2011^{24}\end{array}$ & $\begin{array}{l}\text { Jan } 2004- \\
\text { Jan } 2007\end{array}$ & Bangladesh & Vit A def & New-borns given placebo & 225 & & & 72.9 & & & & & \\
\hline $\begin{array}{l}\text { Coles et } \\
\text { al. } 2001^{23}\end{array}$ & $\begin{array}{l}\text { Oct } 1998- \\
\text { Jun } 1999\end{array}$ & South India & Vit A def & $\begin{array}{l}\text { Child living in area of endemic } \\
\text { Vit A def, of which unknown } \\
\text { proportion received VA dose }\end{array}$ & 464 & & 53.9 & & 64.1 & & 70.2 & & \\
\hline $\begin{array}{l}\text { Darboe et } \\
\text { al. } 2010^{25}\end{array}$ & $\begin{array}{l}\text { Sept } 2001- \\
\text { Oct } 2004\end{array}$ & $\begin{array}{l}\text { The } \\
\text { Gambia }\end{array}$ & Vit A def & $\begin{array}{l}\text { Child living in area of endemic } \\
\text { Vit A def, of which unknown } \\
\text { proportion received VA dose }\end{array}$ & 197 & 1.5 & 78.1 & & & 87.5 & & 78.6 & \\
\hline $\begin{array}{l}\text { Darboe et } \\
\text { al. } 2007^{26}\end{array}$ & $\begin{array}{l}\text { Sept } 2001- \\
\text { Oct } 2004\end{array}$ & $\begin{array}{l}\text { The } \\
\text { Gambia }\end{array}$ & Vit A def & $\begin{array}{l}0-12 m \text { infant receiving } \\
\text { standard WHO Vit A dose } \\
0-12 m \text { infant receiving high- } \\
\text { dose Vit A }\end{array}$ & 197 & $\begin{array}{l}2.0 \\
1.0\end{array}$ & $\begin{array}{l}76.0 \\
80.0\end{array}$ & & & $\begin{array}{l}88.0 \\
88.0\end{array}$ & & $\begin{array}{l}81.0 \\
76.0\end{array}$ & \\
\hline $\begin{array}{l}\text { Verhagen } \\
\text { et al. } \\
2013^{21}\end{array}$ & Aug 2011 & Venezuela & $\begin{array}{l}\text { WHZ or } \\
\mathrm{HAZ}<-2\end{array}$ & $\begin{array}{l}\text { Controls aged } 0-10 y \text { of which } \\
58 \% \text { are acutely or chronically } \\
\text { malnourished }\end{array}$ & 40 & & & & & & & & $\begin{array}{l}70.0 \\
(0-5 y)\end{array}$ \\
\hline $\begin{array}{l}\text { Adegbola } \\
\text { et al. } \\
1994^{12}\end{array}$ & $\begin{array}{l}\text { Nov } 1990- \\
\text { Oct } 1992\end{array}$ & $\begin{array}{l}\text { The } \\
\text { Gambia }\end{array}$ & $\begin{array}{l}\text { WFA }<70 \% \\
\text { NCHS } \\
\text { mean or } \\
\text { oedema }\end{array}$ & $\begin{array}{l}\text { Malnourished children aged } \\
3 m-5 y \text { without pneumonia }\end{array}$ & 100 & & & & & & & & 72.0 \\
\hline $\begin{array}{l}\text { Coles et } \\
\text { al. } 2008^{27}\end{array}$ & $\begin{array}{l}\text { Dec } 2003- \\
\text { July } 2004\end{array}$ & Nepal & Zn def & $\begin{array}{l}\text { Control groups aged } 1-35 \mathrm{~m} \\
\text { given placebo }\end{array}$ & 604 & & & & & & & & 78.7 \\
\hline $\begin{array}{l}\text { Hamer et } \\
\text { al. } 2002^{28}\end{array}$ & Unknown & Ecuador & WAZ & $\begin{array}{l}\text { Healthy 2-60m who were: } \\
\text { Malnourished } \\
\text { Mildly malnourished }\end{array}$ & 210 & & & & & & & & $\begin{array}{l}60.0 \\
72.0\end{array}$ \\
\hline
\end{tabular}




\section{Appendix 1}

Table of STROBE assessment of papers included in systematic review 


\begin{tabular}{|c|c|c|c|}
\hline Reporting Item & Coles et al. $2001^{22}$ & Coles et al. $2011^{24}$ & Coles et al. $2001^{23}$ \\
\hline $\begin{array}{l}\text { Title and Abstract } \\
\text { (1) }\end{array}$ & $\begin{array}{l}\text { (a) Study design in abstract (b) } \\
\text { Informative, clear abstract }\end{array}$ & $\begin{array}{l}\text { (a) Study design in abstract (b) Clear, } \\
\text { balanced summary }\end{array}$ & $\begin{array}{l}\text { (a) Study design outline in abstract (b) Clear } \\
\text { abstract }\end{array}$ \\
\hline $\begin{array}{l}\text { Background/ratio } \\
\text { nale (2) }\end{array}$ & $\begin{array}{l}\text { Spn leading cause of child mortality, } \\
\text { vaccines unavailable. Endemic VA def in } \\
\text { areas of high Spn infection. VA may } \\
\text { reduce carriage rates }\end{array}$ & $\begin{array}{l}\text { Data suggests correlation between endemic } \\
\text { VA def and Spn colonisation in early } \\
\text { infancy }\end{array}$ & $\begin{array}{l}\text { Region-specific data required to form } \\
\text { effective vaccines as serotype prevalence } \\
\text { varies temporally, geographically and by } \\
\text { age. Little data in S. India }\end{array}$ \\
\hline Objectives (3) & $\begin{array}{l}\text { To evaluate the impact of VA on Spn NP } \\
\text { colonisation in young children of endemic } \\
\text { VA def }\end{array}$ & $\begin{array}{l}\text { To evaluate efficacy of new-born VA } \\
\text { supplementation in preventing NP carriage } \\
\text { among } 3 \text { mo old infants in rural Bangladesh }\end{array}$ & $\begin{array}{l}\text { To study the epidemiology of NP } \\
\text { colonisation, risk factors and distribution of } \\
\text { serotypes in S. Indian infants to determine } \\
\text { the effectiveness of conjugate vaccines }\end{array}$ \\
\hline Study design (4) & $\begin{array}{l}\text { Double-blinded, placebo case-controlled } \\
\text { VA supplementation trial }\end{array}$ & $\begin{array}{l}\text { Double-blinded, placebo case-controlled VA } \\
\text { supplementation trial }\end{array}$ & $\begin{array}{l}\text { Double-blinded, placebo case-controlled VA } \\
\text { supplementation trial }\end{array}$ \\
\hline Settings (5) & $\begin{array}{l}\text { South India. Oct 1998-Jan 1999. Area of } \\
\text { endemic VA def }\end{array}$ & $\begin{array}{l}\text { Bangladesh. Jan 2004- Jan 2007. Endemic } \\
\text { VA def }\end{array}$ & $\begin{array}{l}\text { South India, Oct 1998-June 1999. Endemic } \\
\text { VA def }\end{array}$ \\
\hline Participants (6) & $\begin{array}{l}\text { Carriage study from InPACT study } \\
\text { embedded in VASIN trial. Eligibility } \\
\text { criteria, sources, randomisation method } \\
\text { and controls given }\end{array}$ & $\begin{array}{l}\text { Carriage study from JiVitA-2 embedded in } \\
\text { JiVitA1 trial. Criteria given. No } \\
\text { randomisation method given but refers to } \\
\text { JiVitA-2 paper }\end{array}$ & $\begin{array}{l}\text { InPACT study embedded in VASIN trial. } \\
\text { Have to refer VASIN trial for eligibility } \\
\text { criteria and participant details }\end{array}$ \\
\hline Variables (7) & $\begin{array}{l}\text { All variables apart from effect modifiers } \\
\text { given }\end{array}$ & $\begin{array}{l}\text { Exposures, confounding variables given but } \\
\text { not clearly stated. No mention of effect } \\
\text { modifiers }\end{array}$ & $\begin{array}{l}\text { Primary and additional outcomes not clear, } \\
\text { exposures, confounders and effect } \\
\text { modifiers not directly specified }\end{array}$ \\
\hline
\end{tabular}




\begin{tabular}{|c|c|c|c|}
\hline $\begin{array}{l}\text { Data } \\
\text { sources/measure } \\
\text { ments (8) }\end{array}$ & Specimen and lab procedures given & Specimen and lab procedures given & Specimen and lab procedures given \\
\hline Bias (9) & $\begin{array}{l}\text { Minimised. Use of control (selection), re- } \\
\text { interviewed participants at random, } \\
\text { reviewed data collection forms on weekly } \\
\text { basis to avoid missing data, high quality } \\
\text { data collection method }\end{array}$ & $\begin{array}{l}\text { Use of controls and randomisation. } \\
\text { Imbalance in sample size (VA } 275 \text { vs. } \\
\text { placebo } 225 \text { ) reflects survival bias (survival } \\
\text { until } 12 \text { w old) }\end{array}$ & No details of reducing bias \\
\hline Study size (10) & $\begin{array}{l}\text { Study size calculated for intervention data } \\
\text { ( } 464 \text { required to detect } 17.5 \% \text { reduction in } \\
\text { NP colonisation with } 80 \% \text { power). } \\
\text { Placebo group }=232\end{array}$ & $\begin{array}{l}\text { Used data from S. India study (Coles } 2000 \text { ) } \\
-500 \text { infants to detect difference of } 17 \% \text {. } \\
\text { Placebo group }=225\end{array}$ & $\begin{array}{l}3000 \text { embedded in VASIN trial to detect } \\
\text { minimum reduction in infant mortality by } \\
30 \% \text {. No study sample calculation for } \\
\text { InPACT. }\end{array}$ \\
\hline $\begin{array}{l}\text { Quantitative } \\
\text { variables (11) }\end{array}$ & $\begin{array}{l}\text { Grouped according to treatment and } \\
\text { placebo group }\end{array}$ & $\begin{array}{l}\text { Grouped according to treatment and } \\
\text { placebo group }\end{array}$ & Age groups split \\
\hline
\end{tabular}




\begin{tabular}{|c|c|c|c|}
\hline Participants (13) & $\begin{array}{l}\text { Number reported at each stage, non- } \\
\text { participation given, flow diagram given }\end{array}$ & $\begin{array}{l}\text { Number given at each stage, including non- } \\
\text { participants. No flow diagram }\end{array}$ & $\begin{array}{l}\text { Number at each stage given, flow chart } \\
\text { given }\end{array}$ \\
\hline $\begin{array}{l}\text { Descriptive data } \\
\text { (14) }\end{array}$ & $\begin{array}{l}\text { (a) Table } 1 \text { for baseline data (b) number } \\
\text { of participants with missing data given }\end{array}$ & $\begin{array}{l}\text { Baseline characteristics given. No } \\
\text { indication of missed data }\end{array}$ & Demographics in table 1 \\
\hline $\begin{array}{l}\text { Outcome data } \\
\text { (15) }\end{array}$ & $\begin{array}{l}\text { Table } 2 \text { shows number in each exposure } \\
\text { category }\end{array}$ & No table given & $\begin{array}{l}\text { Carriage rates in text given in results } \\
\text { section }\end{array}$ \\
\hline Main results (16) & $\begin{array}{l}\text { Unadjusted and adjusted estimates (OR) } \\
\text { with p-values. Baseline, effect of VA on } \\
\text { colonisation, effect of VA delaying } \\
\text { colonisation, VA on invasive serotype } \\
\text { colonisation, on colonisation with Ab- } \\
\text { resistant pneumococci }\end{array}$ & $\begin{array}{l}\text { Unadjusted and adjusted OR given. } \\
\text { Multivariate models to control for effects of } \\
\text { baseline and other covariates }\end{array}$ & $\begin{array}{l}\text { Carriage rates of unknown proportion } \\
\text { receiving VA given. Adjusted OR given for } \\
\text { risk factors of NP carriage adjusted for } \\
\text { effect of VA in table } 3\end{array}$ \\
\hline $\begin{array}{l}\text { Other analyses } \\
\text { (17) }\end{array}$ & None & None & None \\
\hline Key results (18) & Summarises results, refers to objectives & Summarises & Summarised simply \\
\hline Limitations (19) & $\begin{array}{l}\text { Serum retinol levels at each interval not } \\
\text { measures so VA def is assumed but good } \\
\text { evidence of endemic VA def from } \\
\text { previous studies in same area. Low power } \\
\text { to detect differences between } 2 \text { groups }\end{array}$ & Carriage only measured at $3 \mathrm{mo}$ & $\begin{array}{l}\text { Specimens collected at } 2 \text { mo intervals so } \\
\text { may underestimate true colonisation. States } \\
\text { mothers suffer from night blindness but } \\
\text { does not investigate if infants are VA def }\end{array}$ \\
\hline
\end{tabular}




\begin{tabular}{|l|l|l|l|}
\hline Interpretation (20) & $\begin{array}{l}\text { Interprets with reference to objective, } \\
\text { limitations, compares to previous similar } \\
\text { studies and results }\end{array}$ & $\begin{array}{l}\text { Refers to S. Indian paper and states data } \\
\text { was not significant and VA does not } \\
\text { decrease colonisation. S. Indian paper data } \\
\text { for 4mo. Spn colonisation dynamic process } \\
\text { so may not be valid comparison. Considers } \\
\text { objectives, limitations and current evidence }\end{array}$ & $\begin{array}{l}\text { Comparable data to other regions in } \\
\text { developing world. Few risk factors shows to } \\
\text { modify carriage }\end{array}$ \\
\hline $\begin{array}{l}\text { Generalisability } \\
\mathbf{( 2 1 )}\end{array}$ & $\begin{array}{l}\text { Discusses how results may vary with } \\
\text { different populations, settings and } \\
\text { malnutrition setting }\end{array}$ & $\begin{array}{l}\text { When pooled with S. Indian data, new-born } \\
\text { VA supplementation unlikely to decrease } \\
\text { colonisation }\end{array}$ & $\begin{array}{l}\text { Cannot apply data from study population to } \\
\text { a macroscopic level due to large } \\
\text { socioeconomic differences }\end{array}$ \\
\hline $\begin{array}{l}\text { Other information } \\
\text { - funding (22) }\end{array}$ & $\begin{array}{l}\text { USAID and Institute for Sight and Life, } \\
\text { John Hopkins School of Hygiene and } \\
\text { Public Health }\end{array}$ & $\begin{array}{l}\text { Specimen and lab procedures given } \\
\text { USAID and Institute for Sight and Life, John } \\
\text { Hopkins School of Hygiene and Public } \\
\text { Health }\end{array}$ \\
\hline
\end{tabular}




\begin{tabular}{|c|c|c|c|}
\hline Reporting Item & Darboe et al. $2010^{25}$ & Darboe et al. $2007^{26}$ & Verhagen et al. $2013^{21}$ \\
\hline $\begin{array}{l}\text { Title and Abstract } \\
\text { (1) }\end{array}$ & $\begin{array}{l}\text { (a) Study design in abstract (b) } \\
\text { Informative, clear abstract }\end{array}$ & $\begin{array}{l}\text { (a) Study design in abstract (b) Clear, } \\
\text { balanced summary }\end{array}$ & $\begin{array}{l}\text { (a) Study design outline in abstract (b) } \\
\text { Clear abstract }\end{array}$ \\
\hline $\begin{array}{l}\text { Background/ration } \\
\text { ale (2) }\end{array}$ & $\begin{array}{l}\text { Spn carriage highest in infancy, search for } \\
\text { new vaccine is essential. Need to } \\
\text { understand the distribution and dynamics } \\
\text { of carriage of serotype }\end{array}$ & $\begin{array}{l}\text { Nation polices of VA supplementation in } \\
\text { young children has reduced all-cause } \\
\text { mortality. Higher dose thought to increase } \\
\text { body stores in babies born to VA def } \\
\text { mothers }\end{array}$ & $\begin{array}{l}\text { Lack of data on clinical presentations and } \\
\text { aetiologies of ARTIs in indigenous people } \\
\text { in South America }\end{array}$ \\
\hline Objectives (3) & $\begin{array}{l}\text { To study the longitudinal distribution and } \\
\text { dynamics of Spn carriage of mother/infant } \\
\text { pairs during a high-dose vs low-dose VA } \\
\text { study }\end{array}$ & $\begin{array}{l}\text { To compare efficacy of new-born high-dose } \\
\text { VA supplementation to standard low-dose } \\
\text { suggested by WHO to assess side effects, } \\
\text { VA concentration, mucosal integrity, growth } \\
\text { and morbidity and immunity }\end{array}$ & $\begin{array}{l}\text { To investigate bacterial NP carriage, viral } \\
\text { infections and nutritional status in Enepa } \\
\text { Amerindian children 0-10y with and } \\
\text { without ARTI and their mothers }\end{array}$ \\
\hline Study design (4) & $\begin{array}{l}\text { Cohort longitudinal carriage study } \\
\text { embedded in double-blinded, placebo } \\
\text { case-controlled VA supplementation trial }\end{array}$ & $\begin{array}{l}\text { Double-blinded, placebo case-controlled VA } \\
\text { supplementation trial }\end{array}$ & $\begin{array}{l}\text { Matched-age sibling/cousin case-control } \\
\text { study with and without ARTI cases and } \\
\text { their mothers }\end{array}$ \\
\hline Settings (5) & The Gambia. Sept 2001-Oct 2004 & Bangladesh. Sept 2001 to Oct 2004 & Venezuela August 2011 \\
\hline Participants (6) & $\begin{array}{l}\text { All pregnant women in area and their } \\
\text { infants unless }<2200 \mathrm{~g} \text {, premature }(<37 \mathrm{w}) \text {, } \\
\text { congenital birth defects, severe } \\
\text { peripartum difficulties }\end{array}$ & $\begin{array}{l}\text { All pregnant women in area and their } \\
\text { infants unless }<2200 \mathrm{~g} \text {, premature }(<37 \mathrm{w}) \text {, } \\
\text { congenital birth defects, severe peripartum } \\
\text { difficulties }\end{array}$ & $\begin{array}{l}145 \text { children } 0-10 y \text { in } 5 \text { isolated Enepa } \\
\text { communities diagnosed with ARTI. 0-5y \% } \\
\text { malnourished given as those both acute } \\
\text { (weight-for-height) and chronic (height-for- } \\
\text { age) combined }\end{array}$ \\
\hline
\end{tabular}




\begin{tabular}{|c|c|c|c|}
\hline Variables (7) & Outcomes outlines & Primary and secondary outcomes outlined & $\begin{array}{l}\text { Primary and additional outcomes not } \\
\text { clear, exposures, confounders and effect } \\
\text { modifiers not directly specified }\end{array}$ \\
\hline $\begin{array}{l}\text { Data } \\
\text { sources/measurem } \\
\text { ents (8) }\end{array}$ & Specimen and lab procedures given & $\begin{array}{l}\text { Specimen and lab procedures given, breath } \\
\text { samples for } H \text {. pylori, infant urine for gut } \\
\text { epithelial integrity, breast milk concentration }\end{array}$ & Specimen and lab procedures given \\
\hline Bias (9) & $\begin{array}{l}\text { Randomisation in high-dose VA trial. All } \\
\text { pregnant women in } 6 \text { areas enrolled at } \\
\text { 30w }\end{array}$ & $\begin{array}{l}\text { Randomisation in high-dose VA trial. All } \\
\text { pregnant women in } 6 \text { areas enrolled at 30w }\end{array}$ & No details of reducing bias \\
\hline Study size (10) & $\begin{array}{l}\text { Spn carriage expected at } 80 \% \text { and } \\
\text { sample size of } 220 \text { calculated to detect } \\
18 \% \text { improvement. Recruitment target of } \\
110 \text { per group to allow for drop-outs }\end{array}$ & $\begin{array}{l}\text { Spn carriage expected at } 80 \% \text { and sample } \\
\text { size of } 220 \text { calculated to detect } 18 \% \\
\text { improvement. Recruitment target of } 110 \text { per } \\
\text { group to allow for drop-outs }\end{array}$ & $\begin{array}{l}\text { No study size calculated - } 40 \text { controls and } \\
40 \text { cases. Letter } 46 \text { : case-controls require } \\
\text { calculations, so cases represent cases. } \\
\text { Response }{ }^{47} \text { : "Post hoc power } \\
\text { calculations": Incorrect to calculate power } \\
\text { calculations after study. Cl are accurate } \\
\text { reflection of the strength of associations } \\
\text { and power }\end{array}$ \\
\hline $\begin{array}{l}\text { Quantitative } \\
\text { variables (11) }\end{array}$ & $\begin{array}{l}\text { Grouped according to treatment and } \\
\text { placebo group and split in birth, 2, } 5 \text { and } \\
12 \text { mo groups }\end{array}$ & $\begin{array}{l}\text { Grouped according to treatment and } \\
\text { placebo group and split in birth, 2, } 5 \text { and } \\
12 \mathrm{mo} \text { groups }\end{array}$ & Age groups split \\
\hline
\end{tabular}




\begin{tabular}{|c|c|c|c|}
\hline $\begin{array}{l}\text { Statistical methods } \\
\text { (12) }\end{array}$ & $\begin{array}{l}\text { VA def and Spn carriage compared } \\
\text { between group by Pearson's Chi-squared } \\
\text { test and ANOVA. Modelling used to test } \\
\text { effects of treatment with adjustment for } \\
\text { sex and season }\end{array}$ & $\begin{array}{l}\text { VA def and Spn carriage compared } \\
\text { between group by Pearson's Chi-squared } \\
\text { test and ANOVA. Modelling used to test } \\
\text { effects of treatment with adjustment for sex } \\
\text { and season }\end{array}$ & $\begin{array}{l}\text { Student's t test and non-parametric } \\
\text { Wilcoxon signed rank test - univariate } \\
\text { analysis. Multivariate logistic regression } \\
\text { model for age, sex, nutritional status }\end{array}$ \\
\hline Participants (13) & $\begin{array}{l}\text { Number reported at each stage, non- } \\
\text { participation given, flow diagram given }\end{array}$ & $\begin{array}{l}\text { Number reported at each stage, non- } \\
\text { participation given, flow diagram given }\end{array}$ & $\begin{array}{l}\text { Samples taken from } 79 / 80 \text { children }(99 \%) \text {. } \\
\text { No reason given for missed sample, no } \\
\text { flow chart }\end{array}$ \\
\hline $\begin{array}{l}\text { Descriptive data } \\
\text { (14) }\end{array}$ & $\begin{array}{l}\text { No demographics given in this data but } \\
\text { summarised in corresponding trial paper } \\
\text { in table } 3\end{array}$ & $\begin{array}{l}\text { Baseline characteristics given. No } \\
\text { indication of missed data }\end{array}$ & $\begin{array}{l}\text { Characteristics in table } 1.88 \% \text { cases } \\
\text { malnourished, } 58 \% \text { controls malnourished. } \\
\text { Malnourished = acute and chronic }\end{array}$ \\
\hline Outcome data (15) & $\begin{array}{l}\text { Carriage rates for each serotype at birth, } \\
2,5 \text { and } 12 \mathrm{mo} \text { groups }\end{array}$ & $\begin{array}{l}\text { Carriage rates for each serotype at birth, } 2 \text {, } \\
5 \text { and } 12 \text { mo groups }\end{array}$ & $\begin{array}{l}\text { Carriage rates for cases and controls } \\
\text { combined in table } 2\end{array}$ \\
\hline Main results (16) & $\begin{array}{l}\text { Unadjusted and adjusted estimates (OR) } \\
\text { with p-values. Serotype distribution, infant } \\
\text { age and sex, seasonality, relationship } \\
\text { between mother and infant carriage }\end{array}$ & $\begin{array}{l}\text { Unadjusted and adjusted OR given. } \\
\text { Multivariate models to control for effects of } \\
\text { baseline and other covariates. No } \\
\text { difference in primary outcomes for high- } \\
\text { dose vs low-dose }\end{array}$ & $\begin{array}{l}\text { Cases of ARTI significantly more } \\
\text { malnourished compared to controls. Spn } \\
\text { carriage significantly higher in } \\
\text { malnourished. No statistically significant } \\
\text { relationship with carriage and age. }\end{array}$ \\
\hline Other analyses (17) & None & No adverse events at dosing & $\begin{array}{l}\text { Spn carriage associated with mothers with } \\
\text { lower BMls. No association between } \\
\text { mothers and children }\end{array}$ \\
\hline Key results (18) & Summarises results, refers to objectives & Summarises well & Summarised \\
\hline
\end{tabular}




\begin{tabular}{|c|c|c|c|}
\hline Limitations (19) & $\begin{array}{l}\text { Assumed VA def within population. } \\
\text { Participants had been dosed with VA } \\
\text { supplementation but results found no } \\
\text { detectable effect on pneumococcal } \\
\text { carriage - inclusion in analysis reliable. } \\
\text { Infrequent swabbing, no extension to } \\
\text { other family members }\end{array}$ & $\begin{array}{l}\text { Mechanism by which mortality is reduced is } \\
\text { unknown. Measurement of dose that gives } \\
\text { max reduction needs many large-scale } \\
\text { trials but risk of adverse effects. Low dose } \\
\text { used as control rather than placebo for } \\
\text { ethical considerations }\end{array}$ & $\begin{array}{l}\text { Use of sibling/cousin controls may } \\
\text { underestimate effect of factors relating to } \\
\text { residence and household exposure, e.g. } \\
\text { biomass smoke. Larger cross-sectional } \\
\text { studies required to find association with } \\
\text { carriage and house-hold related factors. } \\
\text { Large } \mathrm{Cl} \text { due to small sample size - data } \\
\text { collection difficult during rainy season and } \\
\text { in rural areas }\end{array}$ \\
\hline Interpretation (20) & $\begin{array}{l}\text { Equilibrium and loss of colonies reached } \\
\text { by } 2 \text { mo. Age dependence of carriage and } \\
\text { relative contribution of mother-infant } \\
\text { transmission differ between vaccine and } \\
\text { non-vaccine serotypes }\end{array}$ & $\begin{array}{l}\text { No evidence to support use of higher VA } \\
\text { dose }\end{array}$ & $\begin{array}{l}\text { Spn carriage is high in children up to } 10 y \\
\text { and chronic malnutrition significantly } \\
\text { associated with increased risk of Spn } \\
\text { carriage - unknown if chronic malnutrition } \\
\text { is a risk factor or whether Spn carriage } \\
\text { affects growth leading to growth deficits } \\
\text { and chronic malnutrition }\end{array}$ \\
\hline $\begin{array}{l}\text { Generalisability } \\
(21)\end{array}$ & $\begin{array}{l}\text { VA shown in other studies to affect } \\
\text { carriage rates so data may not truly reflect } \\
\text { malnourished population once dosed }\end{array}$ & $\begin{array}{l}\text { Reflects general diet disease in Sub- } \\
\text { Saharan Africa. Cannot be extrapolated for } \\
\text { more severe VA def and study does not } \\
\text { have the power to test possibility of a } \\
\text { differential effect on mortality. }\end{array}$ & $\begin{array}{l}\text { Not representative of general population of } \\
\text { Enepa Amerindians or other children due } \\
\text { to the case-control study design }\end{array}$ \\
\hline $\begin{array}{l}\text { Other information - } \\
\text { funding (22) }\end{array}$ & Unknown & Summarised & $\begin{array}{l}\text { Integrated Microsystems for Biosensing } \\
\text { and FUNDIAM }\end{array}$ \\
\hline
\end{tabular}




\begin{tabular}{|c|c|c|c|}
\hline Reporting Item & Adegbola et al. $1994^{12}$ & Coles et al. $2008^{27}$ & Hamer et al. $2002^{28}$ \\
\hline $\begin{array}{l}\text { Title and Abstract } \\
\text { (1) }\end{array}$ & $\begin{array}{l}\text { (a) Study design in abstract (b) } \\
\text { Informative, clear abstract }\end{array}$ & $\begin{array}{l}\text { (a) Study design in abstract (b) Clear, } \\
\text { balanced summary }\end{array}$ & (a) Clinical trial (b) Clear abstract \\
\hline $\begin{array}{l}\text { Background/ration } \\
\text { ale (2) }\end{array}$ & $\begin{array}{l}\text { Pneumonia and malnutrition cause of } \\
\text { mortality in children in the developing } \\
\text { world. Unknown aetiology of pneumonia } \\
\text { in malnourished children }\end{array}$ & $\begin{array}{l}\text { Zinc def high in South Asia. Zinc def } \\
\text { children prone to infections and have higher } \\
\text { incidence of infections. Zinc } \\
\text { supplementation reduces ALRI risk, } \\
\text { unknown if this is due to reducing carriage }\end{array}$ & $\begin{array}{l}\text { Rapid urinary pneumococcal antigen test } \\
\text { (Binax NOW) has excellent sensitivity and } \\
\text { specificity in adults to diagnose } \\
\text { pneumonia but a study has found test to } \\
\text { be positive in Spn carriage in children }\end{array}$ \\
\hline Objectives (3) & $\begin{array}{l}\text { To study the bacteriology and virology of } \\
\text { pneumonia in malnourished children in } \\
\text { the Gambia compared to malnourished } \\
\text { without pneumonia and well-nourished } \\
\text { with and without pneumonia }\end{array}$ & $\begin{array}{l}\text { To study the effect of zinc supplementation } \\
\text { on the association of Spn carriage and risk } \\
\text { of ALRI }\end{array}$ & $\begin{array}{l}\text { To evaluate the Binax NOW assay test in } \\
\text { healthy children aged } 2-60 \text { mo in Ecuador } \\
\text { to determine NP carriage on test results }\end{array}$ \\
\hline Study design (4) & Case-control study - 3 control groups & $\begin{array}{l}\text { Matched case-control study. Population } \\
\text { based, prospective. Embedded within } \\
\text { NNIPS4 trial (trial evaluating zinc, iron and } \\
\text { folic acid prophylaxis on morbidity, mortality } \\
\text { and growth in children 1-35mo old. }\end{array}$ & $\begin{array}{l}\text { Clinical trial of healthy children aged 2- } \\
60 \mathrm{mo}\end{array}$ \\
\hline Settings (5) & The Gambia. Nov 1990-Oct 1992 & Rural Nepal, Dec 2003-July 2004 & $\begin{array}{l}\text { Poor urban neighbourhoods of Quito, } \\
\text { Ecuador. Unknown dates }\end{array}$ \\
\hline
\end{tabular}




\begin{tabular}{|l|l|l|l|}
\hline Participants (6) & $\begin{array}{l}\text { Presenting cases from outpatient for } \\
\text { cases of pneumonia. Malnourished }= \\
\text { WAZ<70\% of NCHS mean or oedema. } \\
\text { Matched-age controls to non-pneumonia } \\
\text { cases. Well-nourished with pneumonia } \\
\text { from ward during study period and without } \\
\text { pneumonia from health centres matched } \\
\text { for age }\end{array}$ & $\begin{array}{l}\text { All children <36mo in NNIPS4 trial during } \\
\text { study period who met criteria for ALRI. } \\
\text { Controls were matched age without ALRI in } \\
\text { last 4w and living in the same area }\end{array}$ & $\begin{array}{l}\text { Healthy children aged 2-60mo living in } \\
\text { study area. Excluded those with fever, } \\
\text { signs of ARTI }\end{array}$ \\
\hline Variables (7) & $\begin{array}{l}\text { Outcomes: bacteriology and virology for } \\
\text { each group. Malnourished with } \\
\text { pneumonia tested for HIV. No mentions of } \\
\text { predictors or effect modifiers. Malnutrition } \\
\text { given but criteria for pneumonia is vague }\end{array}$ & $\begin{array}{l}\text { Outcomes: Colonisation rates in both } \\
\text { groups. Exposures: zinc or placebo. } \\
\text { Confounders: matched age +/- 3mo }\end{array}$ & $\begin{array}{l}\text { Outcomes: positive NP carriage and } \\
\text { positive Binax NOW test result }\end{array}$ \\
\hline $\begin{array}{l}\text { Data } \\
\text { sources/measurem } \\
\text { ents (8) }\end{array}$ & $\begin{array}{l}\text { Lung aspirations, sputum collection. Lab } \\
\text { procedures to examine bacteria and } \\
\text { viruses given }\end{array}$ & NP specimen collection & $\begin{array}{l}\text { Clean-catch midstream urine collected for } \\
\text { Binax NOW test, NP swab 15 minutes } \\
\text { within urine collection }\end{array}$ \\
\hline Bias (9) & $\begin{array}{l}\text { Recruitment bias } \\
\text { 2 people read all test results to reduce } \\
\text { potential variability in interpretation }\end{array}$ \\
\hline
\end{tabular}




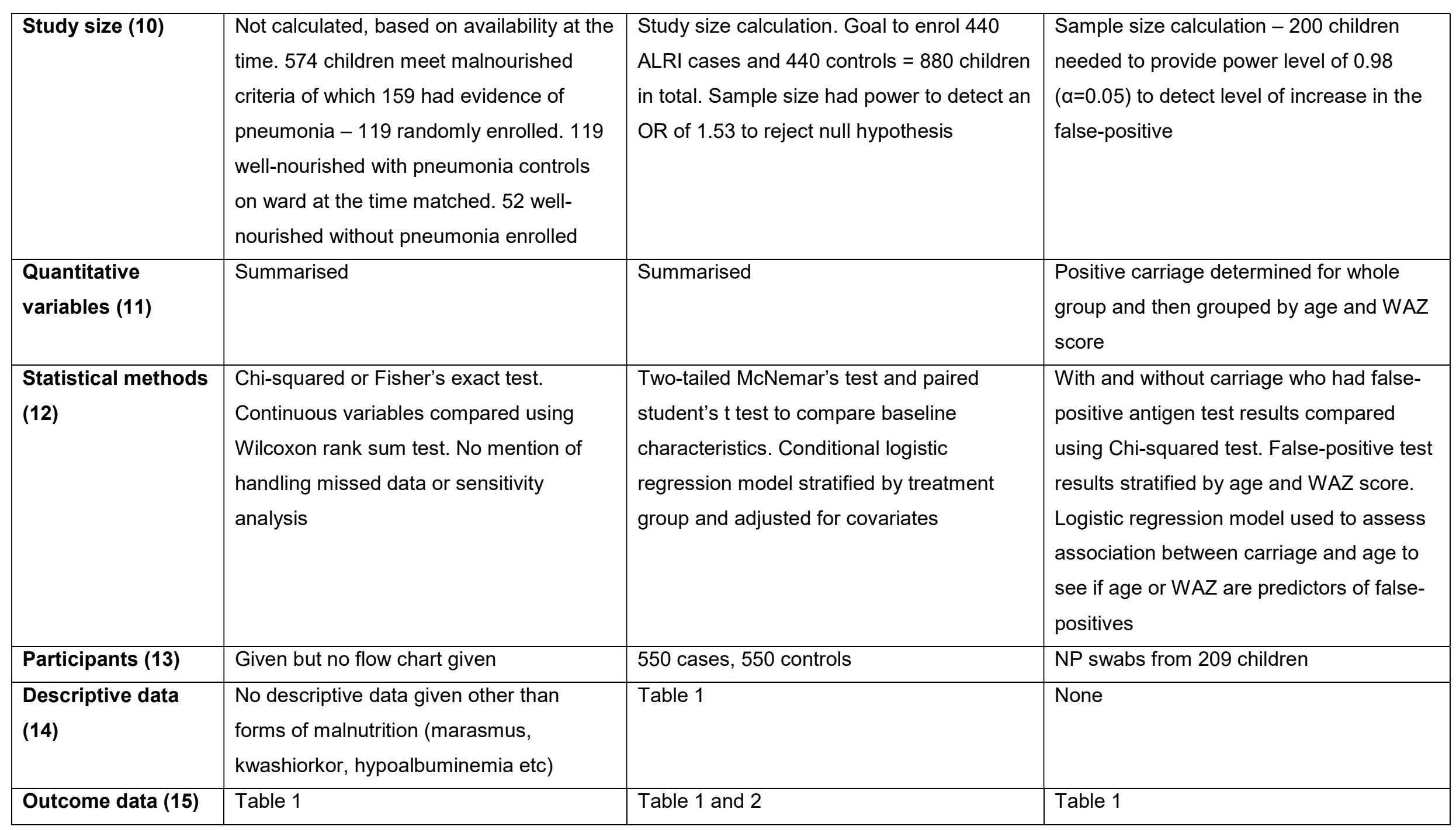




\begin{tabular}{|c|c|c|c|}
\hline Main results (16) & $\begin{array}{l}\text { Aetiology of pneumonia and serotypes. } \\
\text { NP carriage of Spn and H.influenza high } \\
\text { in all groups, isotypes present irrespective } \\
\text { of nutritional status }\end{array}$ & $\begin{array}{l}\text { OR for carriage and risk of ALRI. Zinc } \\
\text { modifies association between carriage and } \\
\text { ALRI. Strong interaction between zinc } \\
\text { status and Spn carriage }\end{array}$ & $\begin{array}{l}\text { False-positives more common in carriers } \\
\text { than non-carriers ( } 21.7 \% \mathrm{v} 4.2 \%) \text {. Carriage } \\
\text { highest in youngest and decreased with } \\
\text { increasing age. No association between } \\
\text { mildly malnourished and malnourished } \\
\text { and carriage rate. No significance } \\
\text { between false-positive results and WAZ } \\
\text { score }\end{array}$ \\
\hline Other analyses (17) & None & $\begin{array}{l}\text { Carriage data in ALRI cases who were } \\
\text { symptomatic at the time for NP swab (table } \\
\text { 2) }\end{array}$ & $\begin{array}{l}\text { No association between WAZ score and } \\
\text { intensity of Spn growth in culture }\end{array}$ \\
\hline Key results (18) & Summarises results, refers to objectives & Summarises well & Summarised \\
\hline
\end{tabular}




\begin{tabular}{|l|l|l|l|}
\hline Interpretation (20) & $\begin{array}{l}\text { Equilibrium and loss of colonies reached } \\
\text { by 2mo. Age dependence of carriage and } \\
\text { relative contribution of mother-infant } \\
\text { transmission differ between vaccine and } \\
\text { non-vaccine serotypes }\end{array}$ & $\begin{array}{l}\text { Zinc helps impede infection process rather } \\
\text { than stop carriage }\end{array}$ & $\begin{array}{l}\text { Similar results as studies in China and the } \\
\text { Gambia }\end{array}$ \\
\hline $\begin{array}{l}\text { Generalisability } \\
\mathbf{( 2 1 )}\end{array}$ & $\begin{array}{l}\text { Only studied community acquired } \\
\text { pneumonia so cannot be applied to } \\
\text { hospital acquired. Can only be applied to } \\
\text { developing countries with similar } \\
\text { spectrum of malnutrition as the Gambia }\end{array}$ & $\begin{array}{l}\text { Zinc effect restricted to the risk of Spn- } \\
\text { carriage related ALRI }\end{array}$ & $\begin{array}{l}\text { Binax NOW antigen test should be used } \\
\text { with caution for pneumonia diagnosis in } \\
\text { young children, especially in developing } \\
\text { countries where carriage rates are high }\end{array}$ \\
\hline $\begin{array}{l}\text { Other information - } \\
\text { funding (22) }\end{array}$ & \begin{tabular}{l} 
Unknown \\
\hline
\end{tabular} & Unknown & Unknown \\
\hline
\end{tabular}

$w=w e e k$

mo=month

$\mathrm{y}=\mathrm{year}$

Spn=S.pneumoniae

$\mathrm{NP}=$ nasopharyngeal

ARTI=Acute Respiratory Tract Infection

ALRI=Acute Lower Respiratory Infection

$\mathrm{VA}=\mathrm{vitamin} \mathrm{A}$

def $=$ deficient/deficiency

WAZ=Weight-for-age $Z$ score

OR=Odds Ratio

$\mathrm{Cl}=$ Confidence Interval 